\title{
Особливості проведення реабілітаційного масажу при дисфункціях м'язів передпліччя
}

\author{
Павло Єфіменко \\ Оксана Каніщева
}

Харківська державна академія фізичної культури, Харків, Україна

\begin{abstract}
Мета: знайти можливість проведення реабілітаційного масажу передпліч при наявності больового синдрому їх м'язів.

Матеріал і методи: дослідження було проведено поточним методом у два етапи. На першому етапі спостереження взяли участь 14 здорових осіб, яким перевіряли реакцію м'язів внутрішньої поверхні передпліч на одну процедуру класичного масажу тільки на відповідних сухожиллях. Методами оцінки ефективності призначали динамометрію та міотонометрію. У другому етапі дослідження взяли участь 7 музикантів з гіпертонусом і м'язовими болями по внутрішній поверхні передпліччя, що виникли за різними причинами. Лікарем було рекомендовано витримати спокій до одного місяця. Проте, в зв'язку з напруженою професійною діяльності ці рекомендації музикантів не влаштували і вони дали згоду прийняти участь у дослідженні. У цій групі застосовували такі методи дослідження: візуально-аналогова шкала болю(Quadruple Visual Analogue Scale (VAS); міотонометрія.

Результати: результати першого етапу проведеного спостереження показали, що після однієї процедури масажу м'язових сухожиль різниця між тонусом спокою та тонусом напруги здорових м'язів - контракція, збільшилась у середньому на 11,7\%. Середній показник динамометрії тієї ж кисті збільшився на 4\%. Результат другого етапу спостереження, проведеного серед осіб зі скаргами на м'язові болі передпліччя, після десяти процедур масажу відповідних сухожиль, виявив зниження больових відчуттів майже у два рази, і зменшення м'язового гіпертонусу у середньому на $11,3 \%$.

Висновки: масаж сухожиль патологічних м'язів дав підставу вважати, що розроблена нами методика масажу має знеболюючий вплив і значно зменшує гіпертонус м'язових тканин. Отримані показники тонусу спокою і рівня болючості м'язів підтверджують позитивний вплив запропонованої нами методики масажу на патологічний стан м'язів передпліч і можливість проведення їх ранньої реабілітації.
\end{abstract}

Ключові слова: патологічні м'язи, реабілітаційний масаж, міотонометрія, динамометрія кисті, масажні прийоми.

\section{Вступ}

Фахова діяльність сучасної людини пов'язана з певними рухами. Одноманітні рухи, кількість яких за робочий день складає десятки тисяч, стають причиною професійних захворювань опорно-рухового апарату, котрі з часом призводять до втрати працездатності. Така людина змушена знижувати виробничий темп, а інколи й робити перерву для лікування та відновлення своєї професійної працездатності.

Серед професійних захворювань опорно-рухового апарату людини найчастіше виникають захворювання верхніх кінцівок, причиною чого є постійне перенапруження. Ця сторона професійної патології включає в себе велику кількість певних хворобливих форм, що вражають різні тканини верхньої кінцівки: м'язи, кістки, периферичні нерви. Найбільш часто патологією вважається фокальна дистонія руки (focal hand dystonia). Вона охоплює переважно людей, які здійснюють висококоординаційні рухи кистю зі значним перевищенням кількості стереотипних рухів за робочий день. Одна з її форм, це невральна, яка проявляється під час навантаження у ви- гляді раптового болю в м'язах, що прогресує на передпліччі або плечі $[7,9]$.

Серед професій, які постійно охоплює ця патологія, часто зустрічається музиканти, особливо ті, хто грає на клавішних, або струнних інструментах. Музикант повинен вміло використовувати можливості кістковом'язової та нервової систем свого організму. Гра на музичному інструменті вимагає контрольованих повторюваних рухів і часто передбачає роботу в неприродній позі протягом довгих годин репетицій і вистав. Подібні навантаження на організм можуть призвести до специфічних порушень опорно-рухового апарату. Крім того, важкі умови роботи: підвищений рівень шуму, тривалий період гри без перерв і напружена підготовка до нового репертуару може вплинути на здоров'я музикантів усіх вікових груп і рівнів майстерності $[1,7,8]$.

Усе це в більшості випадків призводить до стану, який у музикантів називають «переграні руки». У цих випадках починають проводити певні реабілітаційні заходи. Серед розповсюджених і ефективних заходів фізичної терапії, що проводять у подібних ситуаціях, є масаж. 
Однак наявність больового синдрому не завжди дозволяє проводити цю процедуру безпосередньо на таких м'язах і вона тимчасово вважається протипоказаною.

За даними фахівців з фізичної терапії при проведенні реабілітаційного масажу в цьому напрямі застосовують певні системи і методи даної процедури. Так, класична система у більшості випадків наявності больового синдрому м'язових тканин передбачає проведення дренажного масажу вище локалізації запального процесу, витримуючи при цьому визначений час після початку загострення. I тільки після його стухання масажуються безпосередньо патологічні тканини $[3,10]$.

Фахівці, які використовують сегментарно-рефлекторні системи масажу спеціальними прийомами впливають на зони гіперальгезії і гіперестезії м'язових тканин масажем паравертебральних зон спинномозкових сегментів, що іннервують патологічні тканини. Відомого ефекту також досягають масажем симетричних, здорових зон тіла. Наприклад, кінцівки або тулуба [3, 5].

Фахівці, які використовують локальні системи масажу пропонують різні точкові натискування певних ділянок тіла людини. Так, засновник системи Су-джок терапії Пак Де Ву стверджує, що локальний ручний або інструментальний масаж спеціальних зон відповідності усуває больові відчуття при різних патологічних станах тканин соматовегетативної системи людини. Вони складають зони проекції на кистях та стопах у вигляді систем: «основної», «комахи» та «міні» [2]. При наявності больового синдрому м'язових тканин, анальгезуючої та релаксуючої дії досягають проведенням акупресури, тобто точкового масажу певних біологічно-активних точок, та пресації тригерних зон [11, 14].

Серед апаратних методів вібраційний масаж частково або повністю усуває больові відчуття у м'язах після фізичних перевантажень та отриманих травм. Його проводять ручним вібраційним масажером, що виробляє механічні коливання певної частоти. Але в період загострення він також є протипоказанням до проведення такої процедури [6, 10].

Вивчаючи літературні джерела, ми звернули увагу на ствердження фахівців, що розтирання сполучних тканин, а саме м'язових сухожиль, позитивно впливають на трофічні процеси м'язів, до яких вони прикріплюються $[13,15]$. За даними наших попередніх спостережень, при масажі ахіллового сухожилля спостерігалась відповідна реакція у вигляді зменшення температури шкіри в зоні литкового м'яза та покращення показників його тонусу у спокої та напрузі [4].

У нашому випадку ми розглядали можливість отримання релаксуючого ефекту протягом досить короткого проміжку часу, тривалістю до 1 - 2 години після проведення процедури масажу. I тому усі представлені рекомендації цього завдання не вирішують за причини того, що їх дія розрахована на більш тривалий час.

Метою нашого дослідження було знайти можливість проведення реабілітаційного масажу передпліч при наявності больового синдрому їх м'язів.

\section{Матеріал і методи дослідження}

Перший етап спостереження було проведено поточним методом на академічних заняттях з дисципліни «Масаж» зі здобувачами вищої освіти 4 курсу бакалаврату, спеціалізації 017 «Фізична культура і спорт», при вивченні теми «Відновлювальний масаж у короткочасних перервах». У дослідження було залучено 14 осіб, із них 4 чоловіків і 10 жінок, у яких були відсутні скарги на патологічний стан м'язових тканин передпліч. Провели тестування реакції м'язів внутрішньої поверхні передпліч на відповідних сухожиллях на одну процедуру класичного масажу.

Для наочності нами застосовувались такі методи дослідження:

- динамометрія за допомогою кистьового динамометра: для чоловіків ДРП 90; для жінок ДРП 30;

- міотонометрія - механічним міотонометром за аналогією вимірювання міотонометра «Сірмаі», виготовленим на базі індикатора часового типу ич-1. На відміну від аналога, подвійна платформа цього приладу дозволяє при повторному вимірюванні прикладати його до місця реєстрації з однаковим зусиллям і у будь-якому положенні у просторі. Зонд площею 42 мм, у залежності від щільності досліджуваних тканин, під дією внутрішньої пружини поринав у м'які тканини тіла на певну глибину. Повний діапазон руху щупа складав 10 мм, що приймалось за 100\%. Глибина його занурення в поверхневі тканини розраховується у відсотках відносно до повного діапазону руху.

У другому етапі спостереження прийняли участь 7 респондентів - музикантів, з гіпертонусом тканин і м'язовими болями внутрішньої поверхні передпліччя. Причиною больового синдрому стала професійна діяльність. 3 них четверо були гітаристи, два - скрипаля і один піаніст, учасники музикальних колективів, училищ і аматори, які добровільно виявили бажання прийняти участь в даному дослідженні. При відвідуванні лікаря їм було рекомендовано дати спокій кінцівці терміном до одного місяця, що їх не влаштовувало в зв'язку з напруженою роботою, пов'язаною з виконавчою діяльністю. На цьому етапі нами застосовувались такі методи дослідження:

- візуально-аналогова шкала болю (Quadruple Visual Analogue Scale (VAS)). При оцінці інтенсивності болю за ВАШ (VAS) респонденти суб'єктивно визначали інтенсивність свого болю, вказуючи на певну позначку, яка знаходиться на прямій лінії довжиною у 10 сантиметрів. Початок лінії зліва відповідає відсутності больового відчуття, кінець відрізка з правого боку - нестерпним больовим відчуттям;

- міотонометрія.

\section{Результати дослідження}

Дослідження було проведено в наступній послідовності. Положення масажованої людини: сидячи на стільці, передпліччя на столі, тилом кисті доверху. Маркером відмічали крапку на шкірі в зоні черевця м'яза поверхневого згинача пальців. В цій точці заміряли тонус спокою. Потім, в момент вимірювання сили кисті динамометром, фіксували тонус напруги. Показником певних функціональних можливостей обстежуваних м'язів була різниця між тонусом спокою й тонусом напруги - контракція. Чим вона більше, тим вища скорочувальна здібність м'язів. Усі дані були занесені в протокол дослідження.

Далі проводили масаж дистальної половини внутрішньої поверхні передпліччя. Починали почерговим погладжуванням усієї поверхні. Потім повільно, без ривків, розтирали сухожилля від променезап'ясткового суглоба до місць їх прикріплення до м'язів. Після цього розтирали долонну поверхню всієї кисті. Важливою умо- 
Таблиця 1

Результати першого етапу спостереження $(n=14)$

\begin{tabular}{|c|c|c|c|c|c|c|c|c|}
\hline \multirow{2}{*}{ Респондент } & \multicolumn{2}{|c|}{ Початкові показники до масажу } & \multicolumn{3}{|c|}{ Заключні показники після масажу } \\
\cline { 2 - 10 } & $\begin{array}{c}\text { Тонус } \\
\text { спкою } \\
\%\end{array}$ & $\begin{array}{c}\text { Тонус } \\
\text { напруги } \\
\%\end{array}$ & $\begin{array}{c}\text { Контрак- } \\
\text { ція } \\
\%\end{array}$ & $\begin{array}{c}\text { Сила } \\
\text { кисті } \\
\text { кг }\end{array}$ & $\begin{array}{c}\text { Тонус } \\
\text { спокою } \\
\%\end{array}$ & $\begin{array}{c}\text { Тонус } \\
\text { напруги } \\
\%\end{array}$ & $\begin{array}{c}\text { Контрак- } \\
\text { ція } \\
\%\end{array}$ & $\begin{array}{c}\text { Сила } \\
\text { кисті } \\
\text { кг }\end{array}$ \\
\hline Респондент 1 ж & $15,0 \%$ & $24,0 \%$ & $9,0 \%$ & 19 & $12,1 \%$ & $57,0 \%$ & $44,9 \%$ & 25 \\
\hline Респондент 2 ж & $16,0 \%$ & $62,0 \%$ & $46,0 \%$ & 26 & $12,0 \%$ & $66,8 \%$ & $54,8 \%$ & 28 \\
\hline Респондент 3 ж & $21,0 \%$ & $42,0 \%$ & $21,0 \%$ & 21 & $15,0 \%$ & $45,0 \%$ & $30,0 \%$ & 24 \\
\hline Респондент 4 ж & $17,0 \%$ & $39,0 \%$ & $22,0 \%$ & 20 & $15,5 \%$ & $47,4 \%$ & $31,9 \%$ & 24 \\
\hline Респондент 5 ж & $20,0 \%$ & $57,5 \%$ & $37,5 \%$ & 21 & $19,0 \%$ & $58,9 \%$ & $39,9 \%$ & 24 \\
\hline Респондент 6 ж & $15,7 \%$ & $41,0 \%$ & $25,3 \%$ & 19 & $14,0 \%$ & $50,1 \%$ & $36,1 \%$ & 23 \\
\hline Респондент 7 ж & $14,8 \%$ & $39,0 \%$ & $24,2 \%$ & 19 & $13,5 \%$ & $49,6 \%$ & $36,1 \%$ & 24 \\
\hline Респондент 8 ж & $18,0 \%$ & $35,2 \%$ & $17,2 \%$ & 21 & $15,8 \%$ & $47,8 \%$ & $32,0 \%$ & 25 \\
\hline Респондент 9 ж & $16,7 \%$ & $33,6 \%$ & $16,9 \%$ & 20 & $15,0 \%$ & $40,0 \%$ & $25,0 \%$ & 24 \\
\hline Респондент 10 ж & $19,0 \%$ & $37,4 \%$ & $18,4 \%$ & 18 & $16,6 \%$ & $40,0 \%$ & $23.4 \%$ & 23 \\
\hline Респондент 11 ч & $31,0 \%$ & $69,3 \%$ & $38,3 \%$ & 42 & $27,5 \%$ & $78,0 \%$ & $50.5 \%$ & 45 \\
\hline Респондент 12 ч & $26,0 \%$ & $79,0 \%$ & $53,0 \%$ & 40 & $19,0 \%$ & $80,0 \%$ & $61,0 \%$ & 43 \\
\hline Респондент 13 ч & $25,3 \%$ & $70,2 \%$ & $44,9 \%$ & 42 & $20,0 \%$ & $79,0 \%$ & $59,0 \%$ & 44 \\
\hline Респондент 14 ч & $25,2 \%$ & $67,8 \%$ & $42,6 \%$ & 43 & $23,2 \%$ & $78,8 \%$ & $55.6 \%$ & 45 \\
\hline
\end{tabular}

вою при проведенні прийому розтирання було максимальне підвищення рухомості шкіри в зоні масажованої ділянки. Періодично та по завершенні процедури повторювали погладжування. Тривалість масажу була однакова у всіх учасників - 4 хвилини передпліччя й 2 хвилини долонна поверхня кисті. Відразу після такої процедури проводили друге обстеження. Показники результатів вимірювань представлені у таблиці 1.

На першому етапі спостереження ми отримали показники того, що масаж спрямований на сполучні тканини, а саме розтирання м'язових сухожиль внутрішньої поверхні передпліччя, надає позитивної рефлекторної дії на тонус м'язів, як у стані спокою, так і у стані напруження. При цьому ми не враховували можливості виконання інших масажних прийомів, які при патологічному стані м'язів, а саме гіпертонус та біль, протипоказані до їх проведення [3, 5, 6].

3 таблиці 1 видно, що після масажу за запропонованою методикою тонус спокою зменшився в середньому на 3\%, а стан напруги збільшився в середньому на $8,7 \%$. Різниця показника «Контракція» вказує на те, що функціональний стан обстежуваних м'язів покращився в середньому на $11,7 \%$.

Показники динамометрії були підтвердженням того, що контракція позитивно впливає на стан працездатності м'язів у середньому на 4 кг (табл. 1).

Другий етап спостереження, за причини неможливості масажу, безпосередньо м'язових тканин, також проводився в одній групі. Головними показниками стану м'язових тканин була інтенсивність больових відчуттів та тонус спокою.

Результати анкетування за ВАШ показали наявність

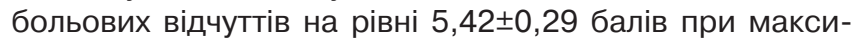
мальному значенні 10 балів. Таким чином, присутній больовий синдром, виявлений у музикантів, є дисфункцією м'язів передпліччя та вагомою причиною дискомфорту.
Усі перелічені респонденти отримали по 10 щоденних процедур класичного масажу за аналогічною методикою першого етапу спостереження. Згідно основних методичних рекомендацій до проведення класичного масажу цю процедуру необхідно проводити поступово, проникаючи до необхідної глибини масажованих тканин, саме тих, які є кінцевою метою масажної процедури. В нашому спостереженні тканини, на які було необхідно впливати, анатомічно знаходились поверхнево. Тому ми застосовували два основних масажних прийоми: погладжування і розтирання. Кожен з них мав певне функціональне призначення. Погладжування за своєю механічною дією було спрямоване на шкіру. Його головна дія в даному випадку була розрахована на адаптацію тканин масажованої поверхні до рук масажуючого та рефлекторне знеболювання за рахунок тертя рук по її поверхні.

Дія розтирання в даному випадку була спрямована на сполучні тканини - сухожилля та їх з'єднання 3 м'язами-згиначами кисті й пальців та прикріпленнями до кісток кисті й пальців. При їх розтиранні інтенсивність прийому зумовлювалась недопущенням значних больових відчуттів. Інші масажні прийоми передбачають більшу інтенсивність рухів, які виконує масажист. Адже при даному стані м'язових тканин це викличе біль, і як захисну реакцію - посилення їх гіпертонусу.

При повторному дослідженні усі учасники відмітили зниження інтенсивності болю. Їх оцінка больових від-

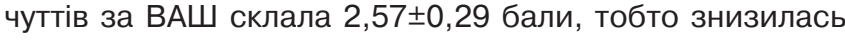
в 2,1 рази $(p<0,05)$. Слід зазначити, що $57 \%$ осіб оцінювали больові відчуття в 2 бали. Показники тонусу спокою м'язових тканин, за якими проводилось спостереження, також зменшились у середньому на 11,3\%. При цьому 5 з них відчували значне послаблення болю вже після 5-6 процедур, що вже було передумовою продовження своєї творчої та професійної діяльності (табл. 2). 
Таблиця 2

Результати виявлення стану запалених м'язів до і після 10 процедур масажу їх сухожиль (n=7)

\begin{tabular}{|l|c|c|c|c|}
\hline \multirow{2}{*}{ Респонденти } & \multicolumn{2}{|c|}{$\begin{array}{c}\text { Початкові показники } \\
\text { до масажу }\end{array}$} & \multicolumn{2}{c|}{$\begin{array}{c}\text { Заключні показники } \\
\text { після масажу }\end{array}$} \\
\cline { 2 - 5 } & $\begin{array}{c}\text { Інтенсивність } \\
\text { болю за шкалою } \\
\text { ВАШ, бали }\end{array}$ & $\begin{array}{c}\text { Тонус спокою } \\
\%\end{array}$ & $\begin{array}{c}\text { Інтенсивність } \\
\text { болю за шкалою } \\
\text { ВАШ, бали }\end{array}$ & $\begin{array}{c}\text { Тонус спокою } \\
\%\end{array}$ \\
\hline Респондент 1 & 6 & $36,7 \%$ & 4 & $28.0 \%$ \\
\hline Респондент 2 & 6 & $38,3 \%$ & 3 & $25,5 \%$ \\
\hline Респондент 3 & 6 & $29,9 \%$ & 2 & $18,1 \%$ \\
\hline Респондент 4 & 5 & $29,8 \%$ & 2 & $17,6 \%$ \\
\hline Респондент 5 & 5 & $30,2 \%$ & 2 & $17,2 \%$ \\
\hline Респондент 6 & 4 & $28,3 \%$ & 2 & $27,5 \%$ \\
\hline Респондент 7 & 6 & $37,9 \%$ & 3 & \\
\hline
\end{tabular}

\section{Висновки / Дискусія}

Проведене дослідження стану гіпертонусу м'язів передпліч у представників професій, пов'язаних з їх постійним перенапруженням, підтвердило неможливість проведення ранньої реабілітації, а саме масажу запалених болючих тканин. Однак, враховуючи те, що до роботи м'язового апарату залучаються сполучні тканини і зокрема сухожилля, нами було запропоновано перевести масажні маніпуляції саме на ці тканини, які практично не відчувають больових відчуттів. На першому етапі нами було досліджено реакцію здорових м'язів внутрішньої поверхні передпліч на одноразовий масаж їх сухожиль. Дане спостереження виявило, що масаж сухожилля позитивно впливає на стан м'язових тканин, зменшенням показників тонусу спокою - розслабленням і підвищенням тонусу напруги - максимальним статичним напру- женням. А зростаюча різниця між цими показниками контракція, вказує на покращення їх функціонального стану, що підтверджується зростанням показника динамометрії кисті.

Другий етап дослідження ми проводили за участю музикантів з «переграними руками». Масаж сухожиль патологічних м'язів дав підставу стверджувати, що розроблена нами методика масажу має знеболюючий вплив і значно зменшує гіпертонус м'язових тканин. Показники тонусу спокою і рівня болючості м'язів вказали на позитивний вплив запропонованої методики масажу і можливість проведення ранньої реабілітації.

Перспективи подальших досліджень у даному напрямку полягають у розробці, перевірці та впровадженні методики при професійних дисфункціях м'язів передпліч на основі різних методів масажу і самомасажу.

Конфлікт інтересів. Автори заявляють, що відсутній конфлікт інтересів, який може сприйматись таким, що може завдати шкоди неупередженості статті.

Джерела фінансування. Ця стаття не отримала фінансової підтримки від державної, громадської або комерційної організації.

\section{Список посилань}

1. Березуцкий В. И., Березуцкая М. С. (2020), «Переигранная рука» или синдромы перенапряжения у музыкантов. Часть I: єтиопатогенез, диагностика», Актуальні проблеми сучасної медицини, Випуск 5, С. 41-49.

2. Брелюс Г. М. (2019), Основи Су-Джок терапії. Дніпро: Середняк Т.К., 138 с.

3. Єфіменко П. Б., Каніщева О. П., Без'язична О. В. (2021), Масаж дітей та дорослих різного віку: навчальний посібник. Харків: ФОП Бровін О.В., 304 с.

4. Єфіменко П. Б., Каніщева О. П. (2019), «Особливості проведення часткового відновлювального масажу після надмірних фізичних навантажень при наявності больового синдрому м'язів», Актуальні питання сучасного масажу: матеріали X Міжнар. наук.-практ. конф., Харків, С. 22-26.

5. І Іаєв Ю. А. (2010), Сегментарно-рефлекторний і точковий масаж в клінічній практиці. Київ: Здоров'я, 320 с.

6. Каніщева О. П. (2014), Масаж та інші засоби відновлення працездатності організму студента: навчальний посібник. Харків: ХНАДУ, 124 с.

7. Капустник В. А., Костюк І. Ф. (2017), Професійні хвороби: підручник, 5-е вид., випр. Київ: Медицина, 536 с.

8. Мазель В. Х. (2002), Музыкант и его руки: Физиологическая природа и формирование двигательной системы. СПб: Композитор, $180 \mathrm{c}$.

9. Мухин Н. А., Косарев В. В., Бабанов С. А., Фомин В. В. (2016), Профессиональные болезни: учебник. Москва: ГЭОТАРМедиа, 512 с.

10. Руденко Р. Є. (2013), Масаж: навчальний посібник. Львів: МультиАрт, 304 с.

11. Усакова Н. А. (2017). Точечный массаж в спортивном зале. Москва: Тигле, 64 с. 


\section{СЛОБОЖАНСЬКИЙ НАУКОВО-СПОРТИВНИЙ ВІСНИК}

12. Art Riggs (2012), Deep Tissue Massage, Revised Edition. Publisher: North Atlantic Books, 254 p.

13. Thomas W. Myers (2014), Anatomy Trains: Myofascial Meridians for Manual and Movement Therapists. Publisher: Churchill Livingstone; 3rd edition, $320 \mathrm{p}$.

14. Clair Davies, Amber Davies (2013), Trigger Point Therapy Workbook, 3rd ed., Oakland, CA: New Harbinger Publications. 376 p.

15. Peter Schwind (2006), Fascial and Membrane Technique: A manual for comprehensive treatment of the connective tissue system, Publisher: Churchill Livingstone. 228 pp.

Стаття надійшла до редакції: 26.03.2021 р.

Опубліковано: 26.04.2021 р.

Аннотация. Павел Ефименко, Оксана Канищева. Особенности проведения реабилитационного массажа при профессиональных дисфункциях мышц предплечий. Цель: найти возможность проведения реабилитационного массажа предплечий при наличии болевого синдрома их мышц. Материал и методы: исследование проводилось в два этапа. Первый этап осуществлялся поточным методом. В нем приняли участие 14 респондентов. Проверялась реакция мышц внутренней поверхности предплечий на одну процедуру классического массажа, который проводили только на соответствующих сухожилиях. Применялись методы исследования: динамометрия, миотонометрия. Во втором этапе наблюдения принимали участие 7 респондентов - музыкантов, с мышечным гипертонусом и болями внутренней поверхности предплечья, возникшие по разным причинам. При посещении врача они получили рекомендацию выдержать покой до одного месяца, что их не устраивало в связи с напряженной исполнительской деятельностью. Поэтому все его участники также составляли одну группу наблюдения. Применялись методы исследования: визуально-аналоговая шкала боли (Quadruple Visual Analogue Scale (VAS); миотонометрия. Результаты: результаты первого этапа проведенного исследования показали, что после одной процедуры массажа мышечных сухожилий, разница между тонусом покоя и тонусом напряжения здоровых мышц - контракция, увеличилась в среднем на 11,7\%. Средний показатель динамометрии той же кисти увеличился на 4\%. Результат второго этапа, проведенного на руках с мышечными болями предплечья, после десяти процедур массажа соответствующих сухожилий, выявил снижение уровня болевых ощущений почти в два раза и снижения гипертонуса мышц в среднем на 11,3\%. Выводы: массаж сухожилий патологических мышц дал основание считать, что разработанная нами методика массажа значительно снижает боль и гипертонус мышечных тканей. Полученные показатели тонуса покоя и уровня болезненности мышц подтверждают положительное влияние предложенной нами методики массажа на патологическое состояние мышц предплечья и возможность проведения их ранней реабилитации.

Ключевые слова: патологические мышцы, реабилитационный массаж, миотонометрия, динамометрия кисти, массажные приемы.

Abstract. Pavlo Yefimenko, Oksana Kanishcheva. Features of rehabilitation massage in professional dysfunction of the forearm muscles. Purpose: to find the possibility of rehabilitation massage, forearms in the presence of pain in their muscles. Material and methods: the study was conducted in two stages. The first stage of observation was carried out by the current method. It was attended by 14 respondents. The reaction of the muscles of the inner surface of the forearms to one procedure of classical massage, which was performed with talcum powder on the corresponding tendons, was checked. Research methods were used: dynamometry, myotonometry. The second stage of the observation was attended by 7 respondents, musicians with hypertension and muscle pain of the inner surface of the forearm, which arose for various reasons. When visiting a doctor, they were advised to stay calm for up to one month, which did not suit them due to the hard work associated with executive activity. Therefore, all its participants also formed one observation group. The following research methods were used: Quadruple Visual Analogue Scale (VAS), myotonometry. Results: the results of the first observation showed that after one procedure of muscle tendon massage, the difference between the tone of rest and the tone of tension of healthy muscles - contraction, increased by an average of 11,7\%. And the average dynamometry of the same brush increased by $4 \%$. The result of the second stage of the observation, conducted on the hands with complaints of muscle pain in the forearm, after ten procedures of massage of the tendons, revealed a reduction in pain almost twice and a decrease in muscle hypertension by an average of $11,3 \%$. Conclusions: massage of tendons of pathological muscles gave reason to believe that the massage technique developed by us has an analgesic effect and significantly reduces the hypertonicity of muscle tissues. The obtained indicators of the tone of rest and the level of muscle pain confirm the positive effect of our proposed massage technique on the pathological condition of the forearm muscles and the possibility of their early rehabilitation.

Keywords: pathological muscles, rehabilitation massage, myotonometry, hand dynamometry, massage techniques.

\section{References}

1. Bezrutskii, V. I., Bezrutskaia, M. S. (2020), «An overplayed hand» or overuse syndrome in musicians. Part I: etiopathogenesis, diagnosis", Aktualni problem suchanoi medycyny, Vypusk 5. pp. 41-49. (in Russ.).

2. Brelius, H. M. (2019), Osnovy Su-Dzhok terapii [Principles of Su Jok therapy]. Dnipro: Seredniak T. K., 138 p. (in Ukr.).

3. Yefimenko, P. B., Kanishcheva, O. P., Bezyazychna, O. V. (2021), Masazh ditei ta doroslykh riznoho viku [Massage for children and adults of all ages]: navchalnyi posibnyk. Kharkiv: FOP Brovin O.V., 304 p. (in Ukr.).

4. Yefimenko, P. B., Kanishcheva, O. P. (2019), «Specific features of partial restorative massage after strenuous physical activity involving muscle pain syndrome», Aktualni pytannia suchasnoho masazhu: materialy X Mizhnar. nauk.-prakt. konf. Kharkiv, pp. $22-26$ (in Ukr.).

5. Isaiev, Y. A. (2010), Sehmentarno-reflektornyi I tochkovyi masazh v klinichnii praktytsi [Reflexosegmental and acupressure in clinical practice], Kyiv: Zdorovia. 320 p. (in Ukr.).

6. Kanishcheva, O. P. (2014), Masazh ta inshi zasoby vidnovlennia pratsezdatnosti orhanizmu studenta [Massage and other means to recover student's body capacity]: navchalnyi posibnyk. Kharkiv: KhNADU, 124 p. (in Ukr.).

7. Kapustnyk, V. A., Kostiuk, I. F. (red.) (2017), Profesiini khvoroby [Occupational diseases]: pidruchnyk, 5-e vyd., vypr. Kyiv: Medytsyna, 536 p. (in Ukr.).

8. Mazel V. Kh. (2002), Muzykant i ego ruki: Fiziologicheskaia priroda I formirovanie dvigatelnoi sistemy [A musician and his hands: The physiological nature and development of motor system]. SPb: Kompositor, 180 p. (in Russ.).

Єфіменко, П., Каніщева, О. (2021), «Особливості проведення реабілітаційного масажу при дисфункціях м'язів передпліччя»
Слобожанський науково-спортивний вісник, № 2(82), С. 57-62, doi:10.15391/snsv.2021-2.009 
9. Mukhin N. A., Kosarev V. V., Babanov S. A., Fomin V. V. (2016), Professionalnyie bolezni [Occupational diseases]: uchebnik. Moskva: GEOTAR-Media, 512 p. (in Russ.).

10. Rudenko, R. Y. (2013), Masazh [Massage]: navchalnyi posibnyk. Lviv: MultiArt, 304 p. (in Ukr.).

11. Usakova, N. A. (2017), Tochechnyi masazh v sportivnom zale [Acupressure in the sport hall]. Moskva: Tigle, 64 p. (in Russ.).

12. Art Riggs (2012), Deep Tissue Massage, Revised Edition, Publisher: North Atlantic Books. 254 p. (in Eng.).

13. Thomas, W. Myers (2014), Anatomy Trains: Myofascial Meridians for Manual and Movement Therapists, Publisher: Churchill Livingstone; 3rd edition. 320 p. (in Eng.).

14. Clair Davies, Amber Davies (2013), Trigger Point Therapy Workbook, 3rd ed., Oakland, CA: New Harbinger Publications, 376 p. (in Eng.).

15. Peter Schwind (2006). Fascial and Membrane Technique: A manual for comprehensive treatment of the connective tissue system. Publisher: Churchill Livingstone, 228 p. (in Eng.).

Received: 26.03.2021.

Published: 26.04.2021.

\section{Відомості про авторів / Information about the Authors}

Єфіменко Павло Богуславович: к.пед.н., професор; Харківська державна академія фізичної культури: вул. Клочківська 99, м. Харків, 61058, Україна.

Ефименко Павел Богуславович: к.пед.н., профессор; Харьковская государственная академия физической культуры: ул. Клочковская 99, г. Харьков, 61058, Украина.

Pavlo Yefimenko: PhD (Pedagogical Sciences), professor; Kharkiv State Academy of Physical Culture: Klochkivska str. 99, Kharkiv, 61058, Ukraine.

ORCID: https://orcid.org/0000-0003-4674-6919

E-mail: pavlo748@gmail.com

Каніщева Оксана Павлівна: к.фіз.вих., доцент; Харківська державна академія фізичної культури: вул. Клочківська 99, м. Харків, 61058, Україна.

Канищева Оксана Павловна: к.физ.восп., доцент; Харьковская государственная академия физической культуры: ул. Клочковская 99, г. Харьков, 61058, Украина.

Oksana Kanishcheva: PhD (Physical education and Sport) assistant professor; Kharkiv State Academy of Physical Culture: Klochkivska str. 99, Kharkiv, 61058, Ukraine.

ORCID: https://orcid.org/0000-0002-5030-5318

E-mail: oksanakan71@gmail.com 